\title{
Stabilization of b-Glucuronidase by Immobilization in Magnetic-Silica Hybrid Supports
}

\author{
Sonali Correa ${ }^{1}$, Magdalena Ripoll ${ }^{1}{ }^{\mathbb{D}}$, Erienne Jackson ${ }^{1}$, Valeria Grazú ${ }^{2,3, * \mathbb{C}}$ and \\ Lorena Betancor $1, *$ (D) \\ 1 Laboratorio de Biotecnología, Universidad ORT Uruguay, Montevideo 11600, Uruguay; \\ correasonali@gmail.com (S.C.); ripoll_m@ort.edu.uy (M.R.); jackson@ort.edu.uy (E.J.) \\ 2 Instituto de Ciencia de Materiales de Aragón (ICMA), Consejo Superior de Investigaciones Científica, \\ Zaragoza 5009, Spain \\ 3 Centro de Investigación Biomédica en Red de Bioingeniería, Biomateriales y Nanomedicina (CIBER-BBN), \\ Planta 0, 28029 Madrid, Spain \\ * Correspondence: vgrazu@unizar.es (V.G.); betancor@ort.edu.uy (L.B.)
}

Received: 28 April 2020; Accepted: 5 June 2020; Published: 13 June 2020

check for updates

\begin{abstract}
Glucuronidases are a class of enzymes that catalyze the breakdown of complex carbohydrates. They have well documented biocatalytic applications in synthesis, therapeutics, and analytics that could benefit from enzyme immobilization and stabilization. In this work, we have explored a number of immobilization strategies for Patella vulgata $\beta$-Glucuronidase that comprised a tailored combination of biomimetic silica $(\mathrm{Si})$ and magnetic nanoparticles (MNPs). The individual effect of each material on the enzyme upon immobilization was first tested. Three different immobilization strategies for covalent attachment on MNPs and different three catalysts for the deposition of Si particles were tested. We produced nine different immobilized preparations and only two of them presented negligible activity. All the preparations were in the micro-sized range (from $1299 \pm 52 \mathrm{~nm}$ to $2101 \pm 67 \mathrm{~nm}$ of hydrodynamic diameter). Their values for polydispersity index varied around 0.3 , indicating homogeneous populations of particles with low probability of agglomeration. Storage, thermal, and operational stability were superior for the enzyme immobilized in the composite material. At $80{ }^{\circ} \mathrm{C}$ different preparations with Si and MNPs retained $40 \%$ of their initial activity after $6 \mathrm{~h}$ of incubation whereas the soluble enzyme lost $90 \%$ of its initial activity within $11 \mathrm{~min}$. Integration of MNPs provided the advantage of reusing the biocatalyst via magnetic separation up to six times with residual activity. The hybrid material produced herein demonstrated its versatility and robustness as a support for $\beta$-Glucuronidases immobilization.
\end{abstract}

Keywords: nanoparticles; $\beta$-glucuronidase; enzyme immobilization; biocatalysis

\section{Introduction}

$\beta$-Glucuronidases ( $\beta$-GIc) is a lysosomal acid hydrolase and member of the glucosidase family that catalyzes the breakdown of complex carbohydrates. It is ubiquitous being found in mammalian tissues and body fluids and also in plants, fishes, insects, and mollusks [1,2]. It elicits different physiological responses as a consequence of the principal function to catalytically cleave the glycosidic bond of glycans. Moreover, $\beta$-GIc is regularly used for in vitro drug metabolism studies, as well as in routine drug testing applications [3]. Glucuronidation (conjugation with glucuronic acid) by the uracil-diphosphate-glucuronosyltransferase (UGT) family of enzymes plays an important role in the metabolic fate of many drugs and other xenobiotics. This biosynthesis reaction also has a role in the conjugation and excretion of endogenous substrates, such as steroids, bilirubin, and bile acids. The glucuronides formed are more polar (water soluble) than the main organic substrate and 
in general excreted through the kidney. Glucuronide tags complicates the direct and quantitative analysis of controlled substances and therefore sample processing necessitates the deconjugation of $\beta$-d-glucuronides from target molecules. $\beta$-GIc cleavage of glucuronide tags is commonly performed in analytical labs as the chemical approach is known to cause the formation of multiple by-products for a given conjugate [4].

Aside from this in vitro application, $\beta$-GIc have an increasing number of biocatalytic utilization in pharmaceutical and food industry [5-7]. For instance, hydrolyzation of one of the glucuronic acid moieties of Glycyrrhizin (GL), a typical triterpenoid saponin efficacious against inflammation, allergy, tumor, and asthma can overcome its low target organ bioavailability. A successful $\beta$-GIc mediated biotransformation of GL not only rendered the target pharmaceutical intermediate but also a functional sweetener that is 940 -fold sweeter than sucrose [5]. $\beta$-GIc has been also used as a tool in enzyme prodrug therapy (EPT) to enable localized conversion of inert inactive prodrugs. Glucuronide prodrugs, including prodrugs of effective antineoplastic activity, do not readily enter cells due to their charged carboxy group, minimizing interactions with endogenous $\beta$-GIc located inside lysosomes. Prodrug activation selectively occurs at target sites where exogenous $\beta$-GIc is applied.

For all the above mentioned applications, integration of $\beta$-GIc to different materials has provided a number of advantages that circumvented the problems associated with the use of the enzyme in its soluble form. In general, enzyme immobilization has proved essential to achieve better specific activities, robustness, and reusability of biocatalysts. However, obtention of active and stable immobilized preparations of enzymes remains a challenge as one is still unable to predict the behavior of an enzyme when cross talking with a particular material. What it is known is that the nature of the carriers as well as the chemistry used to associate them to the biocatalysts may affect the physico-chemical properties of the enzymes and consequently, impact their functionality [8-11]. Given the multiple applications of $\beta$-GIc, the pursuit for better immobilization strategies could still provide better immobilized biocatalysts.

A recent trend in the field of enzyme immobilization is the use of combined or hybrid materials [12,13]. In this approach, different materials are involved with a specific aim in aiding the catalysis, the stability of the biocatalysts, or providing an added advantageous property. Such is the case of a recent composite that we have developed in our laboratory that combined biomimetic silica with magnetic nanoparticles (MNPs) and a horseradish peroxidase. The biomimetic synthesis of silica nanoparticles has various advantages, such as it is a mild and fast reaction, wherein the formation of the nanoparticles takes place within minutes and under neutral $\mathrm{pH}$ and ambient temperatures. Due to its rigid structure it provides stability and enables the reuse of the enzyme. Any material contained in the synthetic mixture may become entrapped within the biomimetic Si nanoparticles [14-17]. The mild synthetic approach is compatible with a range of enzymes for which the strategy has also resulted in stabilization. The synthesis necessitates an aminated molecule to catalyze de deposition of the nanoparticles. Various synthetic polymers (polypeptides and polyamines) as well as biopolymers (proteins and polysaccharides) have been used as inducers for the synthesis. As they become integrated in the support matrix, they provide opportunities to tailor the support for better specific activity and stability of the catalysts. Moreover, integration of MNPs in this particular type of silica supports would allow a facile magnetic separation of the biocatalysts for its reuse or even a remote activation of a thermophilic enzyme upon application of an alternate magnetic field.

In this work, the immobilization of $\beta$-GIc from Patella vulgata was carried out following different strategies under the hypothesis that a tailored combination of materials could produce an active and stable immobilized biocatalyst. Entrapment in biomimetic silica nanoparticles in the presence of three polyaminated molecules: polyethyleneimine, spermidine, and poly-lysine, was first tested followed by immobilization on magnetic nanoparticles (MNPs) via covalent binding and ionic adsorption strategies. Combined silica and magnetic materials were tested proving that tailoring the immobilization strategy resulted essential in the final properties of the immobilized biocatalysts. 


\section{Results and Discussion}

Although immobilization studies are commonly based on trial and error approaches, knowledge of as many properties as possible of the enzyme in advance could dictate the selection of immobilized conditions and help explain the results obtained. $\beta$-GIc from Patella vulgata has shown before to have superior hydrolytic activity on drug-glucuronides [18]. Despite being a commercial enzyme, there is scarce information on its biochemical properties. Its structure has not been elucidated, however, considering the deposited structures of glucuronidases in the Protein Data Bank (PDB) from the Research Collaboratory for Structural Bioinformatics (RSCD)and data compiled in BRENDA (Braunschweig Enzyme Database) it is likely that it is organized as a multimer. An analysis in our laboratory by gel filtration of the commercial preparation using fast protein liquid chromatography (FPLC), showed a main peak of $396 \mathrm{kDa}$ that concentrated all the glucuronidase activity (data not shown). This molecular weight is similar to several tetrameric $\beta$-GIc from other sources [19].

The properties of immobilized biocatalysts on hybrid materials are partially determined by the individual effect of each material on the enzyme upon immobilization [13]. Therefore, as a first step in the integration of $\beta$-GIc in a material containing silica (Si) and MNPs, we studied the entrapment of the enzyme solely in biomimetic Si.

The classical rapid and green one-pot procedure was carried out in the presence of a polyaminated catalyst and derivatives of silicic acid in mild reaction conditions [14]. Silica entrapped preparations were designated as Si@. Because there is a distinct dependence of the amount, size, and form of the silica precipitates on the molecular structure of the polyamine [20,21], we explored the immobilization using polyethyleneimine (PEI), poli Lysine (PL) and spermidine (Spr) (Scheme 1). Upon entrapment using PEI, the immobilization was unsuccessful resulting in Si particles that contained the totality of the offered enzyme with no activity (Table 1).

Further studies demonstrated that the amine catalyst was responsible for the inactivation of the enzyme as incubation with different PEIs (not branched MW 1300, 2000, 60,000. and branched 25,000) inactivated the enzyme after $15 \mathrm{~min}$ at $25^{\circ} \mathrm{C}$ (data not shown). Although PEI has demonstrated in the past to be very useful to stabilize and immobilize enzymes $[9,22]$, it has also been shown that interaction of the polycation with internal pockets of the protein can lead to enzyme inactivation [23].

When using poly-lysine (P-Lys) (MW 70,000-150,000) as amine catalysts, the entrapment resulted in a yield of $49 \pm 2 \%$ and expressed activity of $55 \pm 6 \%$ (Table 1 ). Similar results were obtained for Spr providing two novel immobilized preparations of $\beta$-GIc with this rapid and mild procedure.

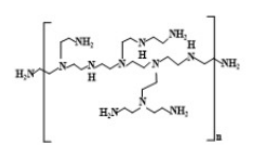

Polyethyleneimine (PEI)

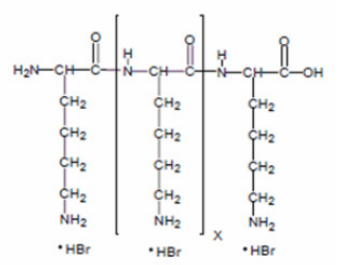

$+\quad \underset{\mathrm{C}}{\mathrm{H} \text { Tetramethyl orthosilicate }}$

(TMOS)

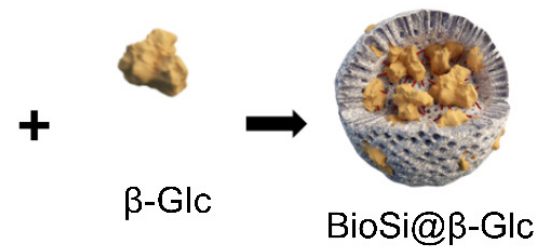

BioSi@ß-Glc

Poly-Lysine (P-Lys)

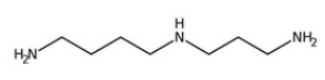

\section{Spermidine}

Scheme 1. Schematic representation of the immobilization strategies using different amine catalysts. 
Table 1. Immobilization of $\beta$-Glucuronidase ( $\beta$-Glc) using different immobilization matrixes.

\begin{tabular}{|c|c|c|c|}
\hline Immobilized Preparation & Immobilization Yield (\%) & Expressed Activity (\%) & Specific Activity* (IU/g) \\
\hline Si@ß-Glc_PEI & $100 \pm 2$ & - & - \\
\hline 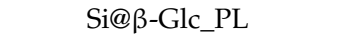 & $49 \pm 2$ & $55 \pm 6$ & $0.45 \pm 0.01$ \\
\hline Si@ $\beta-G l c \_S p r$ & $60 \pm 5$ & $45 \pm 6$ & $0.68 \pm 0.04$ \\
\hline MNP PAA $\beta$-Glc & $4 \pm 1$ & $87 \pm 3$ & $0.16 \pm 0.01$ \\
\hline MNP Amine $\beta$-Glc & $44 \pm 5$ & $55 \pm 6$ & $0.60 \pm 0.01$ \\
\hline MNP DOxi $\beta-G l c$ & $75 \pm 2$ & $82 \pm 3$ & $0.73 \pm 0.01$ \\
\hline Si@ß-Glc_Spr PAA & $70 \pm 4$ & $35 \pm 5$ & $0.34 \pm 0.01$ \\
\hline Si@ß-Glc_Spr Amine & $73 \pm 3$ & $41 \pm 3$ & $0.38 \pm 0.01$ \\
\hline Si@ $\beta$-Glc_Spr DOxi & $72 \pm 1$ & $38 \pm 7$ & $0.48 \pm 0.01$ \\
\hline
\end{tabular}

* Enzyme units per $\mathrm{g}$ of immobilized biocatalyst.

The activity of the immobilized preparations were measured after storage at $4{ }^{\circ} \mathrm{C}$ demonstrating that BioSi@ $\beta$-Glc_PL retained $15 \pm 1 \%$ of the incubated initial activity whereas $58 \pm 1.8$ was preserved in the immobilized preparation using Spr after 7 days (Figure 1).

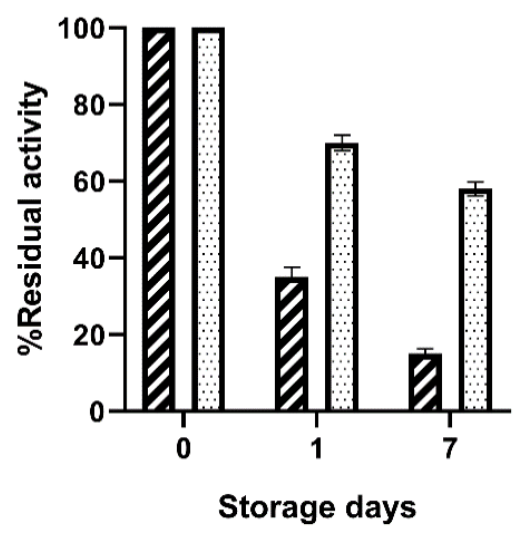

Figure 1. Storage stability at $4{ }^{\circ} \mathrm{C}$ of $\beta$-Glc entrapped in biomimetic silica with spermidine (Spr) (dots) or $\beta$-Glc entrapped in biomimetic silica with poli Lysine (PL) (striped).

The analysis of the supernatant in this experiment showed no enzyme activity indicating negligible leakage from neither of the immobilized preparations. Though the entrapment using PL was successful, the immobilized biocatalysts obtained using Spr showed better potential for further use due to a superior storage stability. The latter was therefore selected for the deposition of silica for subsequent experiments in this work.

The chemistry used for the attachment of an enzyme to a support significantly determines the properties of an immobilized biocatalysts. Different orientations of the biological molecule on the support or number of enzyme-support interactions, can be dictated by the availability of exposed groups on the surface of the enzyme, degree of support functionalization, or conditions that promote enzyme-support reactivity. Both oriented immobilization and intensity of interaction in immobilized enzymes have demonstrated in the past dramatic impacts in the activity, selectivity, and stability of heterogeneous biocatalysts [11,24-26]. We, therefore, studied the immobilization of $\beta$-GIc onto differently functionalized MNPs (Scheme 2) namely MNP PAA for poly aspartic acid activated nanoparticles, MNP Amine for amino silane activated nanoparticles and MNP D for dextran activated nanoparticles. Further chemical modification with sodium periodate of the latter MNPs allowed us to obtain dextran oxidized nanoparticles MNP DOxi. 
1.

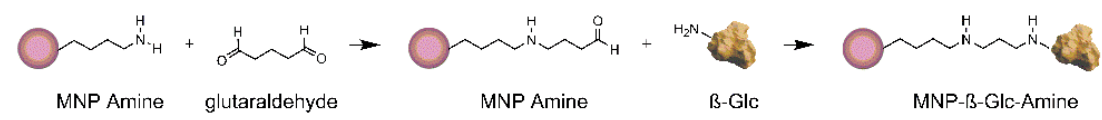

2.

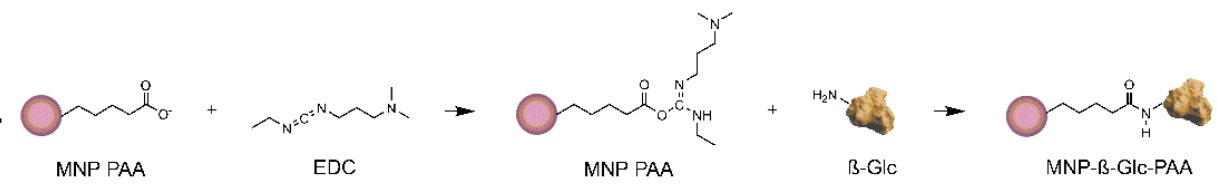

3.

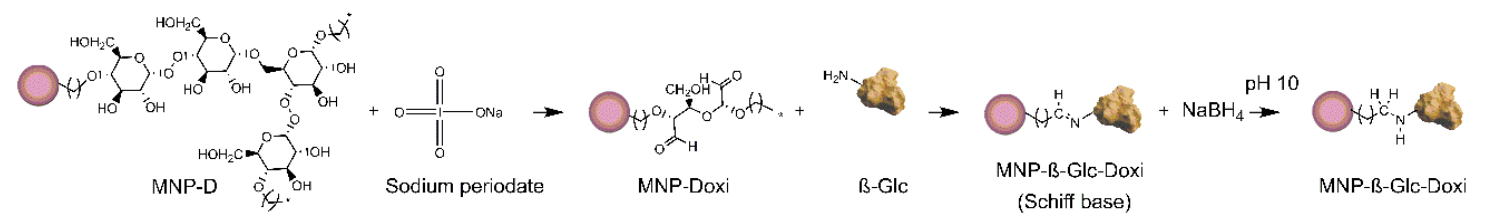

Scheme 2. Schematic representation of the immobilization strategies using differently functionalized magnetic nanoparticles (MNPs).

Following the well-established 1-Ethyl-3-[3-dimethylami-nopropyl]-carbodiimide hydrochloride (EDC) and N-hydroxy succinimide (NHS) chemistry [27], the enzyme was covalently attached via amide bonds on carboxylated MNPs (Scheme 2). Upon immobilization, $4 \pm 1 \%$ of the offered enzyme was attached to the MNPs retaining $87 \pm 3 \%$ of its activity (Table 1 ). Alternatively, aminated MNPs were functionalized with glutaraldehyde for a preferential immobilization via primary amines of the enzyme. In this case, the yield was $44 \pm 5 \%$ and the expressed activity was $100 \%$. Finally, the dextran activated MNPs were mildly oxidized with sodium periodate to create Schiff's bases to which the amines of the enzyme could covalently attach [28]. On further reduction with sodium borohyride the once reversible Schiff's bases are converted into irreversible bonds. Using this approach, the yield obtained was $75 \pm 2 \%$ and a preparation containing $0.73 \mathrm{IU} / \mathrm{g}$ was obtained.

Practical applications of enzymes are often hindered by the instability albeit their capacity to catalyze a wide variety of chemical reactions. Stabilization of biocatalysts is therefore of paramount importance for applied purposes. Thermal stability of the MNPs immobilized enzyme was tested at $75{ }^{\circ} \mathrm{C}$ demonstrating an improved resistance to $\mathrm{T}$ of the immobilized preparations regardless of the chemistry used (Figure 2). MNP PAA preparations were not included in this experiment as they had very poor specific activity. The covalent immobilization of the enzyme on the MNPs provided a significant stabilization to the enzyme. While the soluble enzyme lost $66 \%$ of its initial activity in the first $30 \mathrm{~min}$ of the experiments, both immobilized preparations kept $52.5 \pm 8 \%$ and $38 \pm 3 \%$ after $240 \mathrm{~min}$ for the MNP DOxi and MNP Amine, respectively. It is worth noting that lengthening the incubations at $75^{\circ} \mathrm{C}$ caused precipitation of the soluble preparations and colloidal instability of the particles. Below $75{ }^{\circ} \mathrm{C}$, the immobilized preparations showed remarkable stability which make it unpractical to test their inactivation kinetics. Therefore, in order to consider both the activity of the immobilized biocatalysts and their stability, the lumped parameter catalytic potential (CP) was used. Comparison of the $\mathrm{CP}$ of the preparations showed a three-fold stabilization factor of the immobilized preparations compared to the soluble enzyme as CP were $31.19,96.75$, and $108.1 \mu \mathrm{mol}$ of hydrolyzed 4-methyl-umbelliferyl- $\beta$-d-glucuronide (4-MUG)/g catalyst at $250 \mathrm{~min}$ for the soluble, MNPs Amine and MNPs DOxi respectively. To the best of our knowledge, there is only one previous report of $\beta$-GIc immobilized on a magnetic support [29]. In this case a glucuronidase from P. purpurogenum was immobilized on a graphene $/ \mathrm{Fe}_{2} \mathrm{O}_{3}$ hybrid aerogel. However, no investigation on the thermal stability of the immobilized preparation was conducted. 


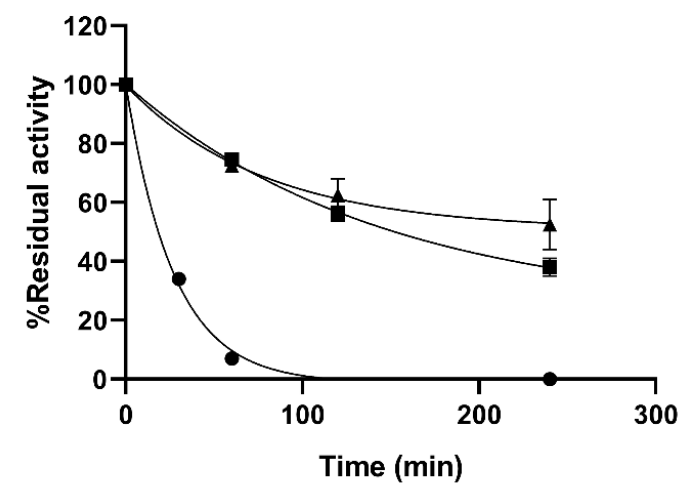

Figure 2. Thermal stability of b-Glc preparations at $75^{\circ} \mathrm{C}$. Soluble b-Glc (circles), b-Glc immobilized onto aminated (100 nm) MNPs (MNP Amine-triangles), b-Glc immobilized onto oxidized carboxylated MNPs (MNP DOxi-squares).

MNPs Amine and MNPs DOxi covalent preparations of $\beta$-GIc were included as part of the mixture in a Si synthesis aiming to integrate both the MNPs and covalently attached enzyme to the Si matrix (Scheme 3). For both preparations it was possible to immobilize more than $70 \%$ of the initial offered activity to the hybrid and approximately $40 \%$ of it remained after the Si entrapment process (Table 1).

1.

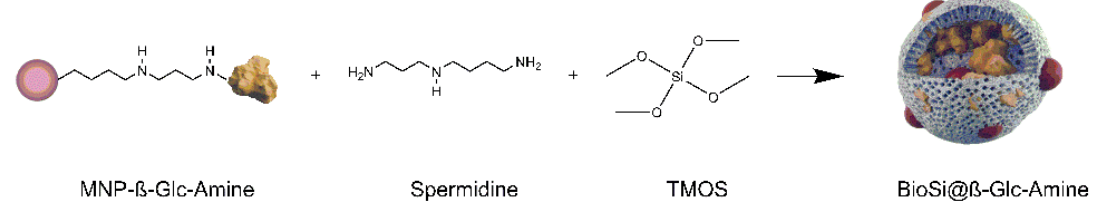

2.

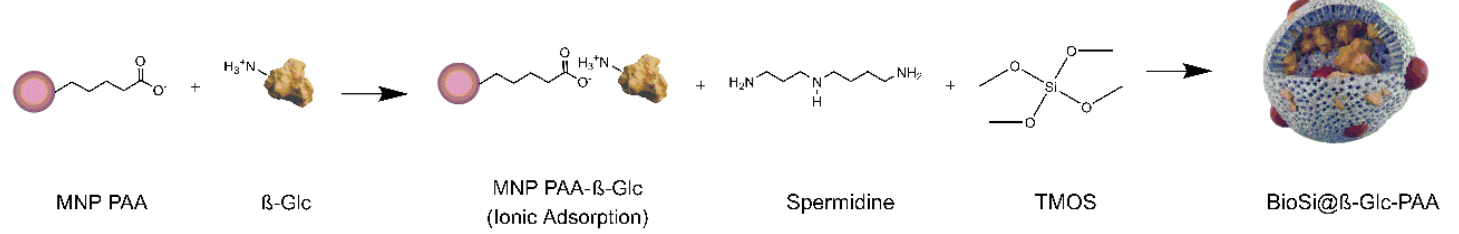

3.

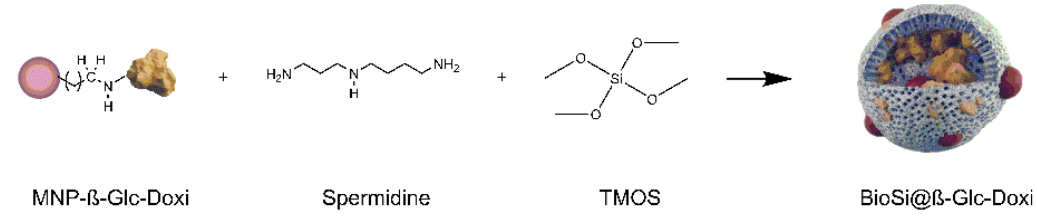

Scheme 3. Schematic representation of the immobilization strategies followed for the entrapment of MNPs immobilized $\beta$-GIc.

Given the poor results obtained following the EDC-NHS chemistry, MNPs PAA were integrated in Si matrix along with the enzyme without previous covalent attachment in further experiments. Previous testing of ionic adsorption of the enzyme on non-modified MNPs PAA revealed a rapid adsorption that produced an immobilized preparation of a similar specific activity of those on MNP Doxi and MNP Amine (0.6 \pm 0.04$)$. Integration in the Si was achieved by following the one-pot synthesis for the co-entrapment and adding MNPs-PAA and the enzyme in the reaction mixture. Similar results than those obtained with the covalently attached enzyme were found upon entrapment of this preparation (Table 1).

Particle size of immobilized preparations could condition their technological application and affect the design of bioprocesses as it can directly impact intrinsic properties such us catalytic potential or robustness $[30,31]$. The hydrodynamic size of the hybrid immobilized preparations prepared herein was evaluated using dynamic light scattering (DLS) (Table 2). 
Table 2. Hydrodynamic size of the immobilized preparations.

\begin{tabular}{ccc}
\hline Immobilized Preparation & Hydrodynamic Size (d.nm) & Polydispersity Index (PDI) \\
\hline BioSi@ $\beta$-Glc_Spr & $2101 \pm 67$ & 0.399 \\
BioSi@ $\beta$-Glc_PAA & $1975 \pm 35$ & 0.317 \\
BioSi@ $\beta$-Glc_Amine & $1299 \pm 52$ & 0.301 \\
BioSi@ $\beta$-Glc_Doxi & $1977 \pm 58$ & 0.327 \\
\hline
\end{tabular}

All the preparations were in the micro-sized range with BioSi@ $\beta$-Glc_Spr showing the largest hydrodynamic diameter. A reduction in the diameter was observed when the MNPs were integrated in the hybrid. The difference was particularly significant when $100 \mathrm{~nm}$ MNPs (BioSi@ $\beta$-Glc_Amine) were used instead of $200 \mathrm{~nm}$ MNPs (BioSi@ $\beta$-Glc_PAA and BioSi@ $\beta$-Glc_Doxi). Regardless of the impact that the size of the MNPs could have, the results correlate with those previously demonstrated by Correa et al. [13] where the MNPs were found to have a profound effect on the silica matrix formation irrespective of the size of the aminated mediator of the Si synthesis. The values for polydispersity index of all the preparations vary around 0.3 , indicating a homogeneous population of particles with a low probability of agglomeration.

The thermal stability at $75^{\circ} \mathrm{C}$ of the hybrid biocatalysts was then tested (Figure 3). Compared to the soluble enzyme, the immobilized preparations were dramatically more thermostable as the soluble enzyme lost $50 \%$ of its activity in the first $20 \mathrm{~min}$ of the experiment while all immobilized biocatalysts retained more than $90 \%$ of its initial activity after 350 min under the same conditions.

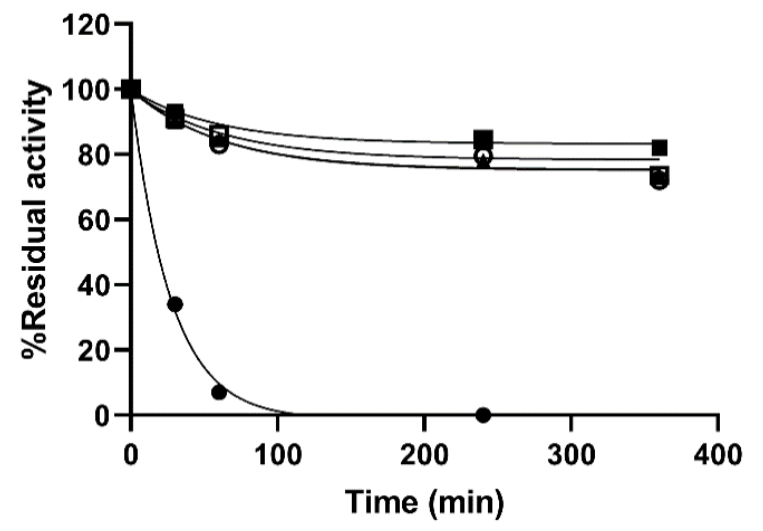

Figure 3. Thermal stability of $\beta$-Glc preparations at $75{ }^{\circ} \mathrm{C}$. Soluble $\beta$-Glc (full circles), $\beta$-Glc entrapped in biomimetic silica with spermidine (Si@ $\beta$-Glc_Spr-open squares), $\beta$-Glc co-entrapped with aminated MNPs (Si@ $\beta$-Glc_Amine-full triangles), $\beta$-Glc co-entrapped with carboxylated MNPs (Si@ $\beta$-Glc PAA—full squares), and $\beta$-Glc co-entrapped with dextran functionalized MNPs (Si@ $\beta$-Glc_DOxi-open circles).

Even increasing the $\mathrm{T}$ to $80{ }^{\circ} \mathrm{C}$ the immobilized preparations preserved $40 \%$ of their initial activity after $6 \mathrm{~h}$ whereas the soluble enzyme lost $90 \%$ of its initial activity within 11 min of experiment (Figure 4). Further increasing of the $\mathrm{T}$ of the thermal stability experiments was not possible due loss of colloidal stability of the particles. Under the conditions tested the $\mathrm{CP}$ of the immobilized preparations were 10 times superior to those of the soluble enzyme $(98.23 \mu$ moles of hydrolyzed 4-MUG/g catalyst for the Si@ $\beta$-GlcDOxi and $10.68 \mu$ moles of hydrolyzed 4-MUG/g catalyst for $\beta$-Glc in $350 \mathrm{~min}$ ). 


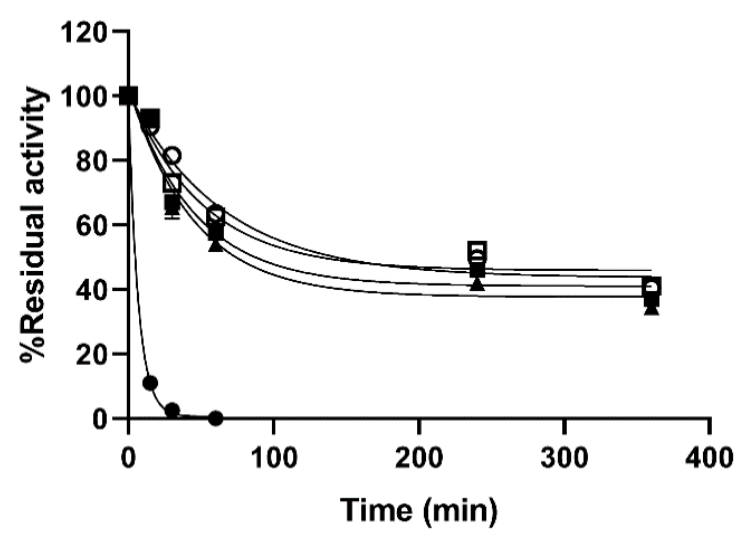

Figure 4. Thermal stability at $80{ }^{\circ} \mathrm{C}$ for soluble $\beta$-Glc (full circles), $\beta$-Glc entrapped in biomimetic silica with spermidine (Si@ $\beta$-Glc_Spr_open squares), $\beta$-Glc co-entrapped with aminated MNPs (Si@ $\beta$-Glc _ Amine-full triangles), $\beta$-Glc co-entrapped with carboxylated MNPs (Si@ $\beta$-Glc_PAA—full squares) and $\beta$-Glc co-entrapped with dextran functionalized oxidized MNPs (Si@ $\beta$-Glc _ DOxi-open circles).

The enhanced stability of $\beta$-GIc particles provides a greater versatility for their use in a wide range of applications. The improved stability of the immobilized enzyme could be a consequence of the constraints imposed by both the rigidity of the covalent attachment to the MNPs and the multiple interactions with the Si matrix that has proven in many instances to have a protective effect on the stability of enzymes [9,32]. Moreover, given the multimeric structure of the enzyme, it is expected that entrapment or crosslinking of its subunits significantly improve its stability as subunit dissociation is often the first step in multimeric enzyme denaturation [33]. Moreover, Spr has been shown to induce positive changes in the secondary and tertiary structures of enzymes that lead to a superior stability [34]. It was not possible to establish a different stabilization factor for the Si alone and the combined Si-MNPs materials as both preparations showed outstanding stability in the conditions tested compared to the soluble enzyme. However, MNPs provides the obvious advantage of ease of separation after desired applications and could also serve as a mean to increase the enzymatic activity via magnetic hyperthermia [13].

Finally, the operational stability of the BioSi@ß-Glc_DOxi was assessed after several enzymatic cycles. In all the studied cycles, the immobilized enzyme was magnetically separated and assessed for its remnant catalytic activity. The enzyme preserved activity up to six reuses (Figure 5). However, a significant loss in activity was observed considering that the experiment was carried out at $37^{\circ} \mathrm{C}$ for $10 \mathrm{~min}$ for each cycle. Although it was proven that the preparation was thermostable, the $\mathrm{pH}$ of the experiment may have affected the performance of the enzyme. In fact, an analysis of the $\mathrm{pH}$ stability of both the $\beta$-Glc and BioSi@ $\beta$-Glc_DOxi demonstrated a low $\mathrm{pH}$ stability at acidic $\mathrm{pHs}$ (Figure S1 (Supplementary Materials)). For $\mathrm{pH}$ 3.0, pH 4.0, and pH 5.5 no activity was recovered after $1 \mathrm{~h}$ of incubation for the soluble or immobilized enzyme. Even at $\mathrm{pH} 7$, only $17.7 \pm 0.1 \%$ of the initial activity was recovered for BioSi@ $\beta$-Glc_DOxi and $11.4 \pm 6.3 \%$ of the $\beta$-Glc was active. For higher pHs, the immobilized preparation showed a superior stability. Albeit the good activity that this enzyme has at acidic $\mathrm{pH}$ we have proven its poor stability under these conditions. Further experiments at shorter time periods would have to be conducted to assess whether the immobilization has provided stabilization at acidic $\mathrm{pHs}$ as was the case for basic $\mathrm{pHs}$. Moreover, an effect of the salts used during the experiments cannot be ruled out. In spite of the activity loss over the cycles, the possibility of reusing the biocatalyst using magnetic separation reinforces the idea of a combined material with added advantages of each of its components. Moreover, our results demonstrated that the hybrid nanocomposites prepared herein, surpass a previous report in thermo stabilization of the enzyme via immobilization [35]. In this work, a PEI-glutaraldehyde derivatized nylon net was used to attach the enzyme and results showed that the preparation suffered a drop in initial activity of more than $90 \%$ at $75^{\circ} \mathrm{C}$ in the first $20 \mathrm{~min}$ of experiment. 


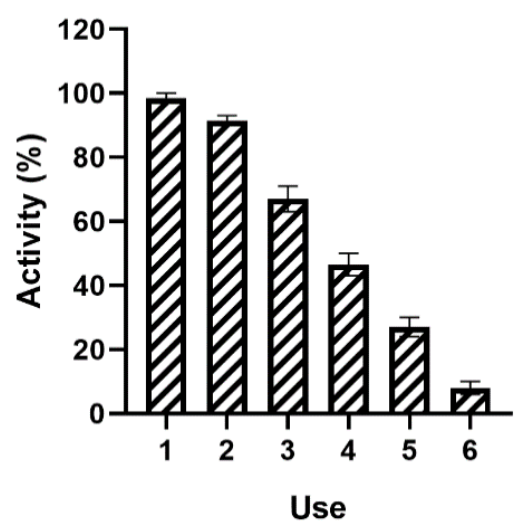

Figure 5. Operational stability of $\beta$-Glc co-entrapped with dextran functionalized oxidized MNPs $(\mathrm{Si} \beta$-Glc_DOxi).

\section{Materials and Methods}

\subsection{Materials}

Patella vulgata limpets $\beta$-glucuronidase enzyme (EC 3.2.1.31), 4-Nitrophenyl $\beta$-D-glucuronide (pNPG), 4-methyl-umbelliferyl- $\beta$-d-glucuronide (4-MUG) (MDL MFCD09039280), polyethyleneimine (PEI) MW 1300, and poly-lysine MW. 70,000-150,000, N-(3-Dimethylaminopropyl)-N'-ethylcarbodiimide (EDC) and N-Hydroxysuccinimide 98\% (NHS) were from Sigma Aldrich (Missouri, EEUU). Bicinconinic acid (BCA), column PD-10 (Sephadex G 25) were from GE Healthcare's Life Sciences (Illinois, EEUU), tetramethyl orthosilicate (TMOS) and dibasic sodium phosphate, 2-ethanesulfonic acid (MES) were from Merck (New Jersey, EEUU), $200 \mathrm{~nm}$ fluidMAG-PAA (MNP PAA), $100 \mathrm{~nm}$ fluidMAG-Amine (MNP Amine), and fluidMAG-D (MNP D) were from Chemicell (Berlin, Germany). All other chemicals used were analytical grade reagents.

\subsection{Enzymatic Assay}

Enzymatic activity was evaluated with a fluorogenic substrate, 4-methyl-umbelliferyl- $\beta$-dglucuronide (4-MUG) (MW $352.29 \mathrm{~g} / \mathrm{mol}$ ). The substrate when cleaved by $\beta$-Glc generates the fluorophore 4-methylumbelliferone (4-MU) (Scheme 4). The excitation and emission wavelengths used to perform the activity measurements were 321 and 447 , respectively.<smiles>Cc1cc(=O)oc2cc(O[C@@H]3O[C@H](C(=O)O)[C@@H](O)[C@H](O)[C@H]3O)ccc12</smiles>

4-Methyl-Umbelliferyl-ß-d-glucuronide (4-MUG)

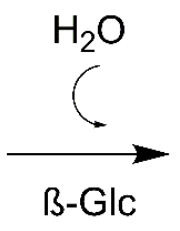

4-Methyl-Umbelliferone (4-MU)<smiles>Cc1cc(=O)oc2cc(O)ccc12</smiles><smiles>O=C[C@H](O)[C@@H](O)[C@H](O)[C@H](O)C(=O)O</smiles>

D-Glucuronic acid

Scheme 4. Generation of 4-methyl-umbelliferyl- $\beta$-d-glucuronide (4-MUG), a fluorescent product, on cleavage by $\beta$-glucuronidase.

For the enzymatic assay with the fluorescent substrate, $225 \mu \mathrm{L}$ of $10 \mathrm{mM}$ MES buffer $\mathrm{pH} 5.5$, $20 \mu \mathrm{L}$ of enzymatic sample and $5 \mu \mathrm{L}$ of a $0.01 \mathrm{mM}$ 4-MUG solution were mixed. It was incubated for $10 \mathrm{~min}$ at $37^{\circ} \mathrm{C}$ in agitation and centrifuged at $13,500 \mathrm{rpm}$ for $5 \mathrm{~min}$. The supernatant was then plated in a 96-well fluorescence plate in a Tecan (Männedorf, Switzerland) plate reader at $37^{\circ} \mathrm{C}$. Using the Magellan 7.2 data analysis software, the relative units of fluorescence per minute (RFU/min) were obtained and used to calculate the units of enzymatic activity. First, a calibration curve of the 4-MU fluorophore, relative fluorescence units (RFU) as a function of concentration (mM) was performed. 
The slope obtained in the calibration curve is used to calculate the reaction rate. The reaction rate is obtained in $\mathrm{mM} / \mathrm{min}$; therefore, the corresponding calculations are made to obtain the units of enzyme activity per milliliter $(\mathrm{IU} / \mathrm{mL})$.

The enzyme unit is defined as the amount of enzyme that catalyzes the conversion of $1 \mu \mathrm{mol}$ of substrate per minute per milliliter of enzyme under the defined test conditions.

\subsection{Immobilization in Biomimetic Silica}

\subsubsection{Physical Entrapment in Biomimetic Si-Polyethyleneimine (PEI)}

$400 \mu \mathrm{L}$ of sodium phosphate buffer $0.1 \mathrm{M}, \mathrm{pH} 7.0,50 \mu \mathrm{L}$ of enzyme $(0.57 \mathrm{mg}), 100 \mu \mathrm{L}$ of $10 \%$ polyethyleneimine solution (PEI) and $100 \mu \mathrm{L}$ of a hydrolyzed TMOS solution prepared by diluting TMOS in hydrochloric acid $(1 \mathrm{mM})$ to a final concentration of $1 \mathrm{M}$ were added to a one-pot synthesis. The mixture was kept standing at $25^{\circ} \mathrm{C}$ for $5 \mathrm{~min}$. It was then centrifuged at $13,500 \mathrm{rpm}$ for $5 \mathrm{~min}$ and the supernatant was collected. To remove ionically absorbed proteins on the surface of the nanoparticles in the silica matrix, the suspension was washed with $10 \mathrm{mM}$ sodium phosphate buffer containing $150 \mathrm{mM} \mathrm{NaCl} \mathrm{pH} \mathrm{7.2.} \mathrm{It} \mathrm{was} \mathrm{then} \mathrm{centrifuged} \mathrm{at} \mathrm{13,500} \mathrm{rpm} \mathrm{for} 5 \mathrm{~min}$. The supernatant was discarded and resuspended in $600 \mu \mathrm{L}$ of $0.1 \mathrm{M}$ sodium phosphate buffer $\mathrm{pH}$ 8.0. This preparation was stored at $4{ }^{\circ} \mathrm{C}$. The enzymatic suspension was measured using the aforementioned enzymatic assay. The immobilization yield and expressed activity was calculated.

Immobilization percentage was defined as:

$$
\% \mathrm{Y}=\frac{(\text { Activity offered }- \text { Activity in supernatant }) * 100}{\text { Activity of fered }}
$$

Expressed activity was defined as:

$$
\% \mathrm{EA}=\frac{(\text { Activity in immobilized preparation }) * 100}{\text { Offered activity }- \text { Activity in supernatant }}
$$

\subsubsection{Physical Entrapment in Biomimetic Si-Poly-Lysine (PL)}

For the final synthesis, we used $100 \mu \mathrm{L}$ of sodium phosphate buffer $0.1 \mathrm{M}, \mathrm{pH} 7.0,50 \mu \mathrm{L}$ of enzyme $(0.57 \mathrm{mg}), 100 \mu \mathrm{L}$ of poly-lysine $(3 \mathrm{mg} / \mathrm{mL})$ and $100 \mu \mathrm{L}$ of hydrolyzed TMOS prepared as in a. The mixture was kept standing at $25^{\circ} \mathrm{C}$ for $5 \mathrm{~min}$. It was then centrifuged at 13,500 rpm for $5 \mathrm{~min}$ and the supernatant was collected. To remove ionically absorbed proteins on the surface of the nanoparticles in the silica matrix, the suspension was washed with $10 \mathrm{mM}$ sodium phosphate buffer containing $150 \mathrm{mM} \mathrm{NaCl} \mathrm{pH} \mathrm{7.2.} \mathrm{It} \mathrm{was} \mathrm{then} \mathrm{centrifuged} \mathrm{at} \mathrm{13,500} \mathrm{rpm} \mathrm{for} 5 \mathrm{~min}$. The supernatant was discarded and resuspended in $600 \mu \mathrm{L}$ of $0.1 \mathrm{M}$ sodium phosphate buffer $\mathrm{pH}$ 8.0. This preparation was stored at $4{ }^{\circ} \mathrm{C}$. The enzymatic suspension was measured using the aforementioned enzymatic assay.

\subsubsection{Physical Entrapment in Biomimetic Si-Spermidine (Spr)}

Similarly, $400 \mu \mathrm{L}$ of sodium phosphate buffer $0.1 \mathrm{M}, \mathrm{pH} 7.0,50 \mu \mathrm{L}$ of enzyme $(0.57 \mathrm{mg}), 100 \mu \mathrm{L}$ of Spermidine and $100 \mu \mathrm{L}$ of hydrolyzed TMOS prepared as in a. were added to a one-pot synthesis. The mixture was kept standing at $25^{\circ} \mathrm{C}$ for $5 \mathrm{~min}$. It was then centrifuged at $13,500 \mathrm{rpm}$ for $5 \mathrm{~min}$ and the supernatant was collected and to the suspension $10 \mathrm{mM}$ sodium phosphate buffer containing $150 \mathrm{mM} \mathrm{NaCl} \mathrm{pH} 7.2$ wash was performed to remove ionically absorbed proteins on the surface of the nanoparticles in the silica matrix. It was then centrifuged at $13,500 \mathrm{rpm}$ for $5 \mathrm{~min}$. The supernatant was discarded and resuspended in $600 \mu \mathrm{L}$ of $0.1 \mathrm{M}$ sodium phosphate buffer $\mathrm{pH}$ 8.0. This preparation was stored at $4{ }^{\circ} \mathrm{C}$. The enzymatic suspension was measured using the aforementioned enzymatic assay. 


\subsubsection{Co-Entrapment of MNPs in $\mathrm{Si}$}

A first washing step of the nanoparticles was carried out to remove detergent residues that come in the commercial solution: $100 \mu \mathrm{L}$ of a $25 \mathrm{mg} / \mathrm{mL}$ fluidMAG-PAA carboxylated nanoparticles solution were washed thrice, with distilled water. A one-pot synthesis was carried out where $400 \mu \mathrm{L}$ of $0.1 \mathrm{M}$ sodium phosphate $\mathrm{pH}$ 8.0, $100 \mu \mathrm{L}$ of a $12 \mathrm{mM}$ spermidine solution (Spr) $\mathrm{pH}$ 8.0, $50 \mu \mathrm{L}$ of $\beta$-Glc $(0.57 \mathrm{mg}), 20 \mu \mathrm{L}$ of MNPs_PAA and $100 \mu \mathrm{L}$ of hydrolyzed TMOS prepared as in a. were mixed and incubated at $25^{\circ} \mathrm{C}$ for $5 \mathrm{~min}$. The resulting preparation was glued to the magnet of the magnetic rack, the supernatant was collected and then the suspension was resuspended in $10 \mathrm{mM}$ sodium phosphate buffer containing $150 \mathrm{mM} \mathrm{NaCl} \mathrm{pH} 7.2$ to remove ionically absorbed proteins on the matrix surface of Si. Finally, it was resuspended in $300 \mu \mathrm{L}$ of $0.1 \mathrm{M}$ sodium phosphate buffer $\mathrm{pH} 8.0$ and stored at $4{ }^{\circ} \mathrm{C}$ during the experiment.

\subsection{Immobilization of $\beta$-Glc on MNPs and Co-Entrapment in Si}

\subsubsection{On MNPs PAA}

To carry out the immobilization of $\beta$-Glc in the commercial magnetite nanoparticles from Chemicell (Berlin, Germany), a first washing step of the nanoparticles was carried out to remove detergent residues that come in the commercial solution. First, $100 \mu \mathrm{L}$ of a $25 \mathrm{mg} / \mathrm{mL}$ fluidMAG-PAA carboxylated nanoparticles solution were washed thrice, with distilled water.

For the covalent immobilization on the MNPs an activation was performed. The nanoparticles were resuspended in $125 \mu \mathrm{L}$ of EDC solution $(5 \mathrm{mg})$ and NHS $(7.5 \mathrm{mg})$ in $10 \mathrm{mM}$ MES pH 5.5 for $30 \mathrm{~min}$ at $37^{\circ} \mathrm{C}$ with stirring. (EDC (MW $\left.=171.91 \mathrm{~g} / \mathrm{mol}\right)$ and NHS $(M W=115.09 \mathrm{~g} / \mathrm{mol})$ ). Then, it was washed twice with $10 \mathrm{mM}$ MES buffer $\mathrm{pH} 5.5$ for $5 \mathrm{~min}$. Subsequently, the enzyme binding stage was performed by incubating the MNPs with $250 \mu \mathrm{L}$ of the enzyme $(0.49 \mathrm{mg} / \mathrm{mL})$ in $10 \mathrm{mM}$ MES pH 5.5 for $60 \mathrm{~min}$ at $37^{\circ} \mathrm{C}$ with constant agitation. Then, a wash with $10 \mathrm{mM}$ MES pH 5.5 was performed for $5 \mathrm{~min}$.

In the case of covalent bonding, an additional step was required to remove the enzyme that had not been covalently bound, but was ionically absorbed, the nanoparticle suspension was incubated with enzyme in $250 \mu \mathrm{L}$ of $10 \mathrm{mM}$ MES pH 5.5 with $300 \mathrm{mM} \mathrm{NaCl}$ for $15 \mathrm{~min}$ at $37^{\circ} \mathrm{C}$ with stirring. Finally, a wash with the aforementioned buffer was performed, and the supernatant and suspension were stored at $4{ }^{\circ} \mathrm{C}$.

The co-entrapment was carried out as mentioned above but instead of the soluble $\beta$-Glc and MNPs added separately, $50 \mu \mathrm{L}$ of the conjugate fluidMAG-Amine-GA- $\beta$-Glc separated using the magnetic rack and resuspended in $50 \mu \mathrm{L}$ of $0.1 \mathrm{M}$ sodium phosphate buffer $\mathrm{pH} 7.0$ was added to the synthesis.

\subsubsection{On MNPs Amine}

FluidMag-Amine MNPs were functionalized with glutaraldehyde. $100 \mu \mathrm{L}$ of a $25 \mathrm{mg} / \mathrm{mL}$ of fluidMAG-Amine MNPs were incubated with $1 \%$ GA for $1 \mathrm{~h}$ at $25^{\circ} \mathrm{C}$. The MNPs were then separated using a magnetic rack and the supernatant was discarded. To this suspension of MNPS Amine activated with glutaraldehyde, $50 \mu \mathrm{L}$ of $\beta$-Glc $(0.57 \mathrm{mg})$ was added and incubated for $30 \mathrm{~min}$ at $25^{\circ} \mathrm{C}$.

The MNP Amine $\beta$-Glc conjugate was separated using the magnetic rack and the solution was resuspended in $50 \mu \mathrm{L}$ of $0.1 \mathrm{M}$ sodium phosphate buffer $\mathrm{pH}$ 7.0. This mixture was then entrapped in $\mathrm{Si}$ using the aforementioned protocol.

\subsubsection{On MNPs D}

A mild oxidation of the $100 \mu \mathrm{L}$ of fluidMAG-D MNPs, dextran functionalized MNPs, was carried out in the presence of $1 \mathrm{mg} / \mathrm{mL}$ of sodium periodate for $1 \mathrm{~h}$ in the dark. $20 \mu \mathrm{L}$ of enzyme $(0.57 \mathrm{mg})$ was then added and incubated at $25^{\circ} \mathrm{C}$ for $1 \mathrm{~h}$. The suspension was separated using a magnetic rack and the activity was measured. The co-entrapment was carried out as mentioned above. Post entrapment, the suspension was resuspended in $0.1 \mathrm{M}$ sodium bicarbonate buffer $\mathrm{pH} 10$ containing sodium 
borohydride $0.1 \mathrm{mg} / \mathrm{mL}$ and was kept in constant agitation for $30 \mathrm{~min}$ at $25^{\circ} \mathrm{C}$. Following which it was centrifuged at 13,500 rpm for $5 \mathrm{~min}$ and washed to remove excess sodium borohydride from the suspension. Finally, the mixture was resuspended in $0.1 \mathrm{M}$ sodium phosphate buffer $\mathrm{pH}$ 7.0.

A control was carried out wherein the _MNP DOxi $\beta$-Glc conjugate once oxidation and immobilization onto the MNP was achieved, the reduction procedure was carried out as mentioned above to the MNPs.

\subsection{Dynamic Light Scattering (DLS) and Z-Potential Measurements}

The measurements were performed on a Zetasizer NanoPlus instrument at $25^{\circ} \mathrm{C}$. Each sample was prepared by diluting the sample $(1: 100,000)$ with milliQ water of which $1 \mathrm{~mL}$ was added to a cuvette. The measurement was repeated 50 times, with a combination of 2 runs per measurement.

\subsection{Thermal Stability Experiments}

The thermal stability activity measurements were carried out at different incubation times to measure the stability of the immobilized enzyme against the soluble enzyme. Both samples were subjected to 70,75 , or $80^{\circ} \mathrm{C}$ in a thermoblock. Aliquots were analyzed at different intervals and the residual activity was calculated as follows:

$$
\text { Residual Activity }=\frac{a}{a_{0}}
$$

where $a$ are the IU at a time point and $a_{0}$ is the initial activity in IU. Biocatalysts inactivation was modelled using the software GraphPad Prism 8.4.0 (San Diego, CA, USA).

The stability factor (SF) was the parameter used for a quantitative comparison of the stability of the biocatalysts. The coefficient of determination, R2, was determined in each case. In order to consider both the activity of the immobilized biocatalysts and their stability, the lumped parameter catalytic potential $(\mathrm{CP})$ was defined:

$$
C P=\int_{t=0}^{t=t_{f}} a_{\text {exp }} d t
$$

$\mathrm{CP}$ was assessed evaluating the thermal stability of the immobilized biocatalysts under non-reactive conditions at 70,75 , or $80^{\circ} \mathrm{C}$ in $25 \mathrm{mM}$ phosphate buffer $\mathrm{pH}$ 7.0. $a_{\text {exp }}$ represents the expressed specific activity in the immobilized catalysts and $t_{f}$ the time for catalyst replacement. In this case, $t f$ is $350 \mathrm{~min}$.

\section{7. $p H$ Stability Experiments}

$\mathrm{pH}$ stability experiments were carried out incubating $20 \mu \mathrm{L}(24 \mathrm{mg})$ of enzymatic sample (soluble or immobilized suspension) for $1 \mathrm{~h}$ at $25^{\circ} \mathrm{C}$ in $1 \mathrm{~mL}$ of the following buffers: $25 \mathrm{mM}$ sodium acetate $\mathrm{pH}$ 3.0, $\mathrm{pH} 4.0$, and $\mathrm{pH} 5.5,25 \mathrm{mM}$ sodium phosphate buffer $\mathrm{pH} 7.0$ and $\mathrm{pH}$ 8.0, $25 \mathrm{mM}$ sodium bicarbonate $\mathrm{pH} 9.0$ and $\mathrm{pH}$ 10.0. Residual activity was calculated as in Equation (3) after measuring the enzymatic activity as previously described.

\subsection{Reuse of Nanohybrid by Magnetic Separation}

The reusability of the immobilized enzyme nanohybrids was studied by repeated usage for 6 enzymatic cycles. Enzymatic reactions using $225 \mu \mathrm{L}$ of $10 \mathrm{mM}$ MES buffer $\mathrm{pH} 5.5,20 \mu \mathrm{L}$ of enzymatic sample and $5 \mu \mathrm{L}$ of a $0.01 \mathrm{mM}$ 4-MUG were incubated for $10 \mathrm{~min}$ at $37^{\circ} \mathrm{C}$ in agitation and centrifuged at 13,500 rpm for $5 \mathrm{~min}$. The supernatant was then plated in a 96-well fluorescence plate in a Tecan (Männedorf, Switzerland) plate reader at $37^{\circ} \mathrm{C}$. Using the Magellan 7.2 data analysis software, the relative units of fluorescence per minute (RFU/min) were obtained and used to calculate the units of enzymatic activity.

Between each cycle, the nanohybrids were carefully separated using a magnetic separator (Chemicell, MagnetoPURE BIG SIZE) and then resuspended in the reaction mixture. The reactions 
were measured as previously described. The activity determined during the first cycle was considered $100 \%$ for the calculation of remaining percentage activity after each use.

\section{Conclusions}

Application of heterogeneous biocatalysts still necessitates careful design of the immobilization approach. The recent use of composite materials has contributed with a new line of investigation in the field, collecting the advantages of several materials for improved performances of biocatalysts. Immobilization matrixes are now regarded as active components of the biocatalyst which could aid in the catalysis or add a property that significantly improves its potential implementation. In this work, we have capitalized on the stabilizing properties of biomimetic $\mathrm{Si}$ and its mild and straightforward synthetic approach that allowed to integrate a previously immobilized enzyme on MNPs. Our results demonstrate the potential and versatility of a mixed matrix composed by biomimetic silica and MNPs used for the first times as a support for producing an active and stable immobilized $\beta$-Glc. Moreover, reports on immobilization of $\beta$-Glc from Patella vulgata are scarce and our work demonstrates a number of novel successful strategies for this enzyme that could increase the possibilities of applications not only for sample preparation in glucuronidated drug analysis but also for the synthesis of new compounds or application in hyperthermia mediated enzyme direct therapy.

Supplementary Materials: The following are available online at http://www.mdpi.com/2073-4344/10/6/669/s1, Figure S1: pH stability of BioSi@ $\beta$-Glc_DOxi (striped) and $\beta$-Glc (dotted).

Author Contributions: S.C., M.R., and E.J.; Validation, M.R.; Formal Analysis, L.B., E.J., and M.R.; Investigation, S.C., and E.J.; Resources, L.B. and V.G.; Data Curation, M.R.; Writing-Original Draft Preparation, L.B. and S.C.; Writing-Review and Editing, V.G., E.J., and M.R.; Visualization, E.J., S.C., and M.R.; Supervision, L.B.; Project Administration, L.B.; Funding Acquisition, L.B. and V.G. All authors have read and agreed to the published version of the manuscript.

Funding: The present work was supported by the grants from the Spanish MINECO BIO2017-84246-C21-R and Fondo Social de la DGA (Grupos DGA) E15_20R grupo de Biofuncionalizacion de Partículas y Superficies BioNanoSurf. The research for this work has received funding from the European Union (EU) project HOTZYMES (grant agreement $n^{\circ}$ 829162) under EU's Horizon 2020 Programme Research and Innovation actions H2020-FETOPEN-2018-2019-2020-01.

Acknowledgments: L.B., S.C., and M.R. thanks PEDECIBA Química, ANII and Universidad ORT Uruguay. We are thankful to Lorena Wilson for fruitful discussion of the data. We also thank R. Mila for help with the Scheme images.

Conflicts of Interest: The authors declare no conflict of interest.

\section{References}

1. Konada, R.S.R.; Venugopal, A.; Nadimpalli, S.K. Purification, biochemical and biophysical characterization of lysosomal $\beta$-D-glucuronidase from an edible freshwater mussel, Lamellidens corrianus. Int. J. Biol. Macromol. 2020, 152, 465-472. [CrossRef] [PubMed]

2. Awolade, P.; Cele, N.; Kerru, N.; Gummidi, L.; Oluwakemi, E.; Singh, P. Therapeutic significance of $\beta$-glucuronidase activity and its inhibitors: A review. Eur. J. Med. Chem. 2020, 187, 111921. [CrossRef] [PubMed]

3. Teitelbaum, A.M.; Flaker, A.M.; Kharasch, E.D. Development, validation and application of a comprehensive stereoselective LC/MS-MS assay for bupropion and oxidative, reductive, and glucuronide metabolites in human urine. J. Chromatogr. B Anal. Technol. Biomed. Life Sci. 2016, 1027, 239-253. [CrossRef] [PubMed]

4. Malik-wolf, B.; Vorce, S.; Holler, J.; Bosy, T. Evaluation of abalone $\beta$-glucuronidase substitution in current urine hydrolysis procedures. J. Anal. Toxicol. 2014, 38, 171-176. [CrossRef] [PubMed]

5. Jiang, T.; Hou, Y.; Zhang, T.; Feng, X.; Li, C. Construction of a CaHPO4-PGUS1 hybrid nanoflower through protein-inorganic self-assembly, and its application in glycyrrhetinic acid 3-O-mono- $\beta$-d-glucuronide preparation. Front. Chem. Sci. Eng. 2019, 13, 554-562. [CrossRef]

6. Kaleem, I.; Rasool, A.; Lv, B.; Riaz, N.; Hassan, J.U.; Manzoor, R.; Li, C. Immobilization of purified B-glucuronidase on $\mathrm{ZnO}$ nanoparticles for efficient biotransformation of glycyrrhizin in ionic liquid/buffer biphasic system. Chem. Eng. Sci. 2017, 162, 332-340. [CrossRef] 
7. Muderrisoglu, C.; Sargin, S.; Yesil-Celiktas, O. Application of $\beta$-glucuronidase-immobilised silica gel formulation to microfluidic platform for biotransformation of $\beta$-glucuronides. Biotechnol. Lett. 2018, 40, 773-780. [CrossRef]

8. Datta, S.; Christena, L.R.; Rajaram, Y.R.S. Enzyme immobilization: An overview on techniques and support materials. 3 Biotech 2013, 3, 1-9. [CrossRef]

9. Cazaban, D.; Illanes, A.; Wilson, L.; Betancor, L. Bio-inspired silica lipase nanobiocatalysts for the synthesis of fatty acid methyl esters. Process Biochem. 2018, 74, 86-93. [CrossRef]

10. López-Gallego, F.; Jackson, E.; Betancor, L. Heterogeneous Systems Biocatalysis: The Path to the Fabrication of Self-Sufficient Artificial Metabolic Cells. Chem.-A Eur. J. 2017, 23, 17841-17849. [CrossRef]

11. Jackson, E.; López-Gallego, F.; Guisan, J.M.; Betancor, L. Enhanced stability of 1 -lactate dehydrogenase through immobilization engineering. Process Biochem. 2016, 51, 1248-1255. [CrossRef]

12. Hwang, E.T.; Gu, M.B. Enzyme stabilization by nano/microsized hybrid materials. Eng. Life Sci. 2013, 13, 49-61. [CrossRef]

13. Correa, S.; Puertas, S.; Gutiérrez, L.; Asín, L.; De La Fuente, J.M.; Grazú, V.; Betancor, L. Design of stable magnetic hybrid nanoparticles of Si-entrapped HRP. PLoS ONE 2019, 14, 1-19. [CrossRef] [PubMed]

14. Jackson, E.; Ferrari, M.; Cuestas-Ayllon, C.; Fernández-Pacheco, R.; Perez-Carvajal, J.; De La Fuente, J.M.; Grazú, V.; Betancor, L. Protein-templated biomimetic silica nanoparticles. Langmuir 2015, 31, 3687-3695. [CrossRef]

15. Lechner, C.; Becker, C. Silaffins in Silica Biomineralization and Biomimetic Silica Precipitation. Mar. Drugs 2015, 13, 5297-5333. [CrossRef] [PubMed]

16. Liu, J.; Yang, Q.; Li, C. Towards efficient chemical synthesis via engineering enzyme catalysis in biomimetic nanoreactors. Chem. Commun. 2015, 51, 13731-13739. [CrossRef]

17. Karthikeyan, S.; Kurt, Z.; Pandey, G.; Spain, J.C. Immobilized Biocatalyst for Detection and Destruction of the Insensitive Explosive, 2,4-Dinitroanisole (DNAN). Environ. Sci. Technol. 2016, 50, 11193-11199. [CrossRef]

18. Combie, J.; Blake, J.W.; Nugent, T.E.; Tobin, T. Morphine glucuronide hydrolysis: Superiority of $\beta$-glucuronidase from Patella vulgata. Clin. Chem. 1982, 28, 83-86. [CrossRef]

19. Pellock, S.J.; Walton, W.G.; Biernat, K.A.; Torres-Rivera, D.; Creekmore, B.C.; Xu, Y.; Liu, J.; Tripathy, A.; Stewart, L.J.; Redinbo, M.R. Three structurally and functionally distinct -glucuronidases from the human gut microbe Bacteroides uniformis. J. Biol. Chem. 2018, 293, 18559-18573. [CrossRef]

20. Qiu, Y.; Lin, Y.; Zhang, G. Unique silica biomimetic mineralization of acidic elastin-like polypeptides without hydroxyl and charged residues. Int. J. Biol. Macromol. 2020, 153, 224-231. [CrossRef]

21. Pawolski, D.; Heintze, C.; Mey, I.; Steinem, C.; Kröger, N. Reconstituting the formation of hierarchically porous silica patterns using diatom biomolecules. J. Struct. Biol. 2018, 204, 64-74. [CrossRef] [PubMed]

22. Virgen-Ortíz, J.J.; Dos Santos, J.C.S.; Berenguer-Murcia, Á.; Barbosa, O.; Rodrigues, R.C.; Fernandez-Lafuente, R. Polyethylenimine: A very useful ionic polymer in the design of immobilized enzyme biocatalysts. J. Mater. Chem. B 2017, 5, 7461-7490. [CrossRef] [PubMed]

23. Mazzaferro, L.; Breccia, J.D.; Andersson, M.M.; Hitzmann, B.; Hatti-Kaul, R. Polyethyleneimine-protein interactions and implications on protein stability. Int. J. Biol. Macromol. 2010, 47, 15-20. [CrossRef] [PubMed]

24. Romero-Fernández, M.; Paradisi, F. Protein immobilization technology for flow biocatalysis. Curr. Opin. Chem. Biol. 2020, 55, 1-8. [CrossRef]

25. López-Gallego, F.; Fernandez-Lorente, G.; Rocha-Martín, J.; Bolivar, J.M.; Mateo, C.; Guisan, J.M. Multi-Point Covalent Immobilization of Enzymes on Glyoxyl Agarose with Minimal Physico-Chemical Modification: Stabilization of Industrial Enzymes. In Immobilization of Enzymes and Cells; Guisan, J.M., Bolivar, J.M., López-Gallego, F., Rocha-Martín, J., Eds.; Springer: New York, NY, USA, 2020; pp. 93-107.

26. Boudrant, J.; Woodley, J.M.; Fernandez-Lafuente, R. Parameters necessary to define an immobilized enzyme preparation. Process Biochem. 2020, 90, 66-80. [CrossRef]

27. Bart, J.; Tiggelaar, R.; Yang, M.; Schlautmann, S.; Zuilhof, H.; Gardeniers, H. Room-temperature intermediate layer bonding for microfluidic devices. Lab Chip 2009, 9, 3481-3488. [CrossRef]

28. Orrego, A.H.; Ghobadi, R.; Moreno-Perez, S.; Mendoza, A.J.; Fernandez-Lorente, G.; Guisan, J.M.; Rocha-Martin, J. Stabilization of immobilized lipases by intense intramolecular cross-linking of their surfaces by using aldehyde-dextran polymers. Int. J. Mol. Sci. 2018, 19, 553. [CrossRef]

29. Chen, L.; Wei, B.; Zhang, X.; Li, C. Bifunctional graphene/ $\gamma$-Fe2O3 hybrid aerogels with double nanocrystalline networks for enzyme immobilization. Small 2013, 9, 2331-2340. [CrossRef] 
30. Dal Magro, L.; de Moura, K.S.; Backes, B.E.; de Menezes, E.W.; Benvenutti, E.V.; Nicolodi, S.; Klein, M.P.; Fernandez-Lafuente, R.; Rodrigues, R.C. Immobilization of pectinase on chitosan-magnetic particles: Influence of particle preparation protocol on enzyme properties for fruit juice clarification. Biotechnol. Rep. 2019, 24, e00373. [CrossRef]

31. Illanes, A.; González, J.M.; Gómez, J.M.; Valencia, P.; Wilson, L. Diffusional restrictions in glyoxyl-agarose immobilized penicillin $\mathrm{G}$ acylase of different particle size and protein loading. Electron. J. Biotechnol. 2010, 13, 1-10. [CrossRef]

32. Jackson, E.; Correa, S.; Betancor, L. In Situ Immobilization of Enzymes in Biomimetic Silica. In Immobilization of Enzymes and Cells; Guisan, J.M., Bolivar, J.M., López-Gallego, F., Rocha-Martín, J., Eds.; Springer: New York, NY, USA, 2020; pp. 259-270.

33. Fernandez-Lafuente, R. Stabilization of multimeric enzymes: Strategies to prevent subunit dissociation. Enzyme Microb. Technol. 2009, 45, 405-418. [CrossRef]

34. Hosseini-Koupaei, M.; Shareghi, B.; Saboury, A.A.; Davar, F.; Raisi, F. The effect of spermidine on the structure, kinetics and stability of proteinase K: Spectroscopic and computational approaches. RSC Adv. 2016, 6, 105476-105486. [CrossRef]

35. Canales, I.; Manjón, A.; Iborra, J.L. Immobilization of $\beta$-glucuronidase on pelicular nylon. Biocatalysis 1991, 4, 277-290. [CrossRef]

(C) 2020 by the authors. Licensee MDPI, Basel, Switzerland. This article is an open access article distributed under the terms and conditions of the Creative Commons Attribution (CC BY) license (http://creativecommons.org/licenses/by/4.0/). 